\title{
A GUERRA DOS ALFABETOS: OS POVOS INDÍGENAS NA FRONTEIRA ENTRE O ORAL E O ESCRITO
}

\author{
Bruna Franchetto
}

Entre as experiências mais marcantes da história do encontro entre populações indígenas e colonizadores estão a descoberta, a entrada, a aquisição e o impacto da escrita, com seus inevitáveis corolários: alfabetização, letramento e escolarização. Instrumentos delicados e ao mesmo tempo poderosos nas mãos dos agentes "civilizadores", essas experiências operam mudanças significativas nas sociedades indígenas. Pouco se tem refletido sobre este tema no âmbito da história dos povos indígenas no Brasil e pouco se tem ouvido o que os índios dizem e contam sobre ele.

Ao ter como pano de fundo o confronto entre oralidade e escrita, no momento da introdução da escrita numa sociedade de tradição oral, o ponto deste ensaio é o sistema de concomitantes e contraditórias representações da escrita que surgem, interagem, defrontam-se a partir dos diversos atores em cena. Trato aqui a escrita como metáfora ou emblema, o que remete para além da sua aparente natureza imediata de técnica de transformação de códigos. São assim analisadas as representações que diversos atores em relação elaboram sobre o sentido da escrita e como tais representações dizem respeito à imagem que cada um faz do(s) outro(s) e às dinâmicas políticas subjacentes às metáforas ortográficas. Trata-se, então, de uma interpretação do "sentido da escrita" que pode ajudar a explicar, entre outras coisas, as razões de certo fracasso dos projetos da chamada "educação bilíngüe".

Pretendo investigar aspectos da transformação de uma língua oral em língua escrita a partir de uma posição privilegiada para a observação do cruzamento e do embate de ideologias e práticas que configuram o campo da chamada "educação indígena" e de suas articulações dentro de uma arena maior. Trata-se da posição de quem exerce o métier de lingüista dedicado ao estudo de línguas indígenas e criador e manipulador de alfabetos, de normas da escritura, desde as transcrições nos cadernos de campo até as cartilhas para a alfabetização. Não será então sobre os rituais da alfabeti- 
zação nem sobre as variadas e complexas conseqüências da introdução da escrita via escolarização nas sociedades indígenas que pretendo me deter, mas sim sobre certas conotações da escrita, distinguindo aspectos funcionais do leque de conotações não-funcionais e fortemente ideologizadas que a acompanham

Há hoje em dia um consenso difuso quanto ao poder de cura de programas de educação escolar em língua indígena diante dos males causados por uma prática ineficaz quando se trata de garantir direitos "universais" às populações indígenas e que condena sumariamente as línguas nativas ao desaparecimento. Os personagens em jogo não concordam, todavia, quanto à natureza desses males e quanto aos resultados que se querem da cura. As diferentes propostas de ortografia e as variadas representações sobre o significado de letras ou grafemas tornam-se espelhos de ideologias em confronto.

A história de qualquer sistema ortográfico caracteriza-se por mudanças e adaptações. Qualquer novo sistema de escrita constitui-se e é reformulado na dependência de fatores que, além de serem de natureza "técnica" ou "científica", são políticos, ativos ou reativos. Há em curso no Brasil, e não começou ontem, mas está cada vez mais acirrada e violenta, uma verdadeira guerra dos alfabetos, cujos combatentes são pequenos exércitos de missionários, membros de órgãos governamentais e não-governamentais, lingüistas, assessores. Em meio a essa guerra, os índios aliam-se ora a uns, ora a outros, avançando ou recuando, negociando.

\section{Entre os índios escolarizados de Roraima}

No final dos anos 80, encontrava-me em Roraima, estado do extremo norte brasileiro, realizando pesquisas lingüísticas nas aldeias Taurepáng, etnia de língua karib. A notícia da presença de um lingüista, na época personagem raro na região, provocou de imediato o interesse de índios e de órgãos governamentais e não-governamentais locais (Secretaria Estadual de Educação, Delegacia do Ministério da Educação, Diocese, entidades indigenistas). Acabava de chegar a Roraima o modelo da "educação bilíngüe" para as escolas indígenas, sintoma de modernização, de progresso, da disposição de instituições governamentais e missionárias de aceitarem novos princípios em gestação no próprio Ministério da Educação.

Fui alvo de convites para assessorar, como lingüista, programas e projetos de natureza educacional na área escolar voltados para a população indígena de Roraima. Tratava-se de algo mais do que um convite: o lingüista 
era chamado compulsivamente a aplicar seus conhecimentos especializados a fim de avaliar propostas, resolver problemas, ministrar cursos, elaborar cartilhas de alfabetização. Visitei, assim, ao longo de três anos, além dos Taurepáng, algumas Maloca ${ }^{1}$ dos Macuxi, povo também de língua karib, e os Wapichana, etnia de língua aruak, na região entre a savana do lavrado e as serras orientais, conversando sobre escola, ortografias e alfabetização em língua indígena. ${ }^{2}$ Em todas as Malocas havia uma escola e nela aconteceu a maior parte das reuniões e encontros. Toda e qualquer reflexão sobre a educação bilíngüe em si decorria necessariamente de uma discussão em torno de uma "nova" escola, na qual o uso oral e escrito das línguas indígenas e a alfabetização em língua indígena estariam presentes ao lado da língua oficial, o português.

Entre missionários, agentes do governo e assessores, qual era a posição dos índios? Quais as representações de Macuxi e Wapichana sobre a educação escolar, na fronteira de uma passagem abrupta da estigmatização e da crise de suas línguas nativas em face da avalanche de propostas de uso dessas línguas em programas de educação bilíngüe? Havia um vácuo que permitia nutrir expectativas e discursos contraditórios. Nas falas indígenas recorria-se a termos como "aculturação" e "resgate" lingüístico e cultural.

Encontrei todo um leque de posições. Num extremo estava uma aversão explícita a todo tipo de intervenção escolar formal, como mostra o radicalismo conservador de um velho líder taurepáng da Maloca de Sorocaima:

Não permito escolas na minha maloca. Eu mesmo posso educar meus filhos [...] Já vieram muitos para fundar escolas lá, mas sempre falei que não é essa a educação que importa. Eu sei ensinar a plantar, vender os produtos e comprar coisas boas... Eu estou vendo que as crianças que estão indo na escola estão ficando mal-educadas. Só querem bater bola e bater nos outros (Depoimento do tuxáua Mário Flores Macário, 1986, Diocese de Roraima, Boletim n.11, s/p).

Em Sorocaima, onde toda a comunidade é fiel da Igreja Adventista do Sétimo Dia, não havia escolas; a língua taurepáng se mantinha viva, inclusive nos quase obsessivos e diários cultos adventistas.

No outro extremo, um pequeno grupo de Macuxi e Wapichana procurava há alguns anos um caminho próprio para a revitalização de suas línguas, com a consciência nítida do seu processo de aniquilamento; a sua introdução na escola, aproveitando estrategicamente as brechas abertas pela "moda" da educação bilíngüe, poderia ter uma milagrosa função de resgate. Nas malocas macuxi e, sobretudo, wapichana, visitadas em 1988, 
encontrei um típico quadro de perda lingüística e ruptura geracional. Os mais velhos, muitos dos quais monolíngües, utilizavam a língua indígena integralmente; seus filhos, bilíngües, comunicavam-se com os pais na língua materna e com os filhos em português; estes, mesmo que ainda pudessem entender seus avós, expressavam-se exclusivamente usando o português. Na geração intermediária, era comum ouvir frases como: "Entendo tudo mas, para falar, a língua é dura, parece que se enrola, não consigo dizer meus pensamentos", ou "Só falo gíria quando eles [os filhos] não entendem o que estou mandando, quando fico brava".

A escolarização foi o principal veículo de repressão lingüística e cultural, desde as escolas fundadas pelo Serviço de Proteção aos Índios, nos anos 20 e 30, aos internatos católicos, abrangendo a difusão das escolas estaduais e municipais nas regiões do interior de Roraima a partir dos anos 50. Pude observar, nos obsessivos rituais disciplinadores e nas pantomimas folclóricas caricaturais das comemorações oficiais, como o acesso das populações indígenas à escolarização produzia não mais do que semi-analfabetos formados para assumirem tarefas de mão-de-obra submissa e explorada.

Entre os Macuxi e os Wapichana havia um discurso articulado sobre os valores da instrução escolar e da escrita como uma tecnologia desejável para a superação de uma crônica situação de inferioridade. Ao mesmo tempo, falava-se dos valores da identidade étnica, emblematizados pela alteridade ou pela diversidade lingüística, em um discurso que, embora nascido sob as asas dos missionários católicos, estava tomando rumos autônomos. Tratava-se de um grupo de lideranças políticas, no qual os mais jovens, todos egressos dos centros de formação da Diocese, apoiados na experiência e na sabedoria de alguns velhos líderes, procuravam experimentar métodos e soluções independentes das ortodoxias missionárias e oficiais.

Entre os pólos representados pelo discurso do tuxáua Taurepang de Sorocaima e pelas propostas de jovens líderes wapichana, que de modos opostos manifestavam atitudes de valoração da alteridade, estava uma maioria de descrentes, daqueles que ou tinham interiorizado os estigmas (e o medo), ou não esperavam mais nenhuma mudança que pudesse levar a escola a formar verdadeiros alfabetizados, pelo menos na língua oficial nacional, ou ainda mantinham rigidamente separados os espaços do "caboclo" e do "civilizado", ${ }^{3}$ não aceitando nenhuma proposta de introdução das línguas indígenas na escola.

O trabalho e a convivência com os Wapichana de Malacaxeta, em Roraima, marcaram minha iniciação como "lingüista assessor". É esta experiência que enfoco a seguir, já que ela me parece oferecer uma exemplificação interessante do tema deste artigo: o embate dos alfabetos. 


\section{Uma arena ortográfica: ideologias em confronto entre os Wapichana}

No começo do ano de 1987, um pequeno grupo de professores wapichana ${ }^{4}$ da escola da maloca de Malacaxeta, a poucos quilômetros de Boa Vista, capital do estado de Roraima, me procurou, com um apelo quase dramático, para que assessorasse de imediato um projeto de revisão das ortografias wapichana e de elaboração de cartilhas para a alfabetização ou o ensino da língua na escola. Os professores sentiam-se pressionados de vários lados: pela própria consciência da agonia de sua língua materna; pelo incentivo ao resgate lingüístico formulado pelos missionários católicos e pelo recémcriado Núcleo de Educação Indígena da Secretaria de Educação do Governo do então chamado Território de Roraima; em função da desconfiança e das críticas manifestadas por moradores destacados da Maloca e por setores do próprio governo quanto à necessidade e à viabilidade de tal projeto.

O pequeno grupo wapichana, que já tinha iniciado uma discussão a respeito das várias grafias coexistentes de sua língua, expressava dúvidas e um considerável embaraço. Cada uma das grafias tinha a aparência de um objeto definitivo, de um código escrito uniforme, uma vez homogeneizadas as eventuais variações dialetais internas ao wapichana. Os índios queriam escolher, ou melhor, queriam gerar uma outra escrita, marcando distância de missionários, católicos e protestantes que, proponentes das ortografias existentes, os sitiavam em campos opostos. Essa nova ortografia deveria ser apresentada ao Estado como emblema de uma unidade, a dos Wapichana brasileiros, neutralizando as divisões religiosas. Finalmente oficializada, ela permitiria uma operação, utópica, de resgate e salvamento: o ensino do wapichana como segunda língua nas escolas das Malocas onde já não era mais usado pelas gerações escolarizadas e em via de escolarização.

\section{A escrita dos crentes}

O wapichana tinha começado a sua existência como língua escrita nos anos 50, na sede da Unevangelized Field Mission da Guiana Inglesa (UFM). A partir daí, o sistema ortográfico elaborado pelos evangélicos atravessou a fronteira e foi trazido para as comunidades wapichana no Brasil por missionários e índios, em suas andanças ou em viagens como agentes de proselitismo religioso. A escrita "crente" passou, desde então, a circular informalmente não apenas entre os segmentos diretamente ligados à Missão, como também foi adotada pelos poucos índios catequizados na fé católica, 
mas alfabetizados em sua língua materna durante períodos de permanência entre os evangélicos da Guiana.

Na época de minha chegada a Roraima, eram esses indivíduos os mais antigos e sofisticados letrados em wapichana e os que transmitiam o uso da escrita, em sua versão "crente", a outros; eram ainda eles os que visitavam com certa regularidade os postos da Missão evangélica e freqüentavam as reuniões com os missionários, a fim de se aprimorarem no domínio da escrita e da leitura e terem acesso aos materiais impressos em wapichana. Esses materiais, produzidos principalmente na Guiana, incluíam cartilhas, manuais, livros de histórias, livros de cantos religiosos e textos evangélicos. Não havia nada que se comparasse no Brasil à quantidade e à qualidade da produção escrita de origem "crente". O sistema ortográfico elaborado pela UFM tinha sido estabelecido a partir de critérios e processos que são comuns a todas as missões evangélicas fundamentalistas, pioneiras na transformação ortográfica de línguas de culturas de tradição oral e na alfabetização de populações indígenas. Um mesmo padrão de estilo de pesquisa de campo, de investigação lingüística, de estabelecimento de escritas, de filosofia e técnicas de alfabetização, de material impresso para escolas e igrejas caracteriza o trabalho dessas missões. ${ }^{5}$

A poliglossia e o poder da tradução interlingüística são características importantes da visão evangélica pentecostalista. Elas constituem, junto com a redução à escrita de línguas ágrafas e a educação bilíngüe, um mesmo aparato para a integração e a assimilação de populações indígenas, concretizando a vocação "civilizatória" da escrita do Ocidente e, paradoxalmente, legitimando as línguas indígenas. Onde estiverem presentes os evangélicos, eles a seu modo "preservam" o uso das línguas indígenas e são, como me disseram os Macuxi da maloca de Napoleão, "os únicos civilizados a não terem vergonha de falar gíria". ${ }^{6}$ A que se deve essa peculiaridade das missões evangélicas de fazerem do estudo "científico" das línguas indígenas e da sua transformação em línguas escritas, usadas em seguida em programas educacionais, um aspecto fundamental de sua tarefa de conversão e de sua atuação "civilizadora"? Podemos destacar dois elementos definidores desse conjunto missionário: a natureza da tarefa evangelizadora e a sua vocação civilizadora.

Evangelizar é, literalmente, levar "a boa nova" a todos os povos do mundo; tornar acessível a todos os homens, independente de sua cultura, sistema social e língua, a "palavra de Deus", reificada para a eternidade como verdade universal nos textos sagrados cristãos. Na visão pentecostalista, o poder de dominar as equivalências entre palavras e expressões de línguas diferentes é o dom mais importantes do cristão iluminado pelo Espírito Santo. 
Afinal, se Jesus Cristo apregoou que todos os povos deviam se abrir à luz do Evangelho, os povos indígenas, pagãos, não podem continuar "inocentes" e devem ter a chance de conhecer as Sagradas Escrituras. A frase "Se Deus está interessado em mim, por que não fala a minha língua?" pode ser lida nos folhetos que circulam entre missionários. Para fazer acessível o Evangelho a todos os povos é preciso dominar a língua de cada povo, tornar escritas as línguas ainda ágrafas, traduzir os textos sagrados, alfabetizar os indivíduos em via de conversão e os convertidos para que sejam os leitores e os reprodutores da palavra de Deus. São estas as etapas necessárias ao trabalho do missionário evangélico.

Acrescente-se a isto a tarefa "civilizadora". Todas essas missões costumam definir-se explicitamente como "agentes de mudança" — uma mudança profunda impingida não apenas pelos valores veiculados aos poucos através das leituras evangélicas, mas também pela simples presença ou convivência imposta pelos missionários à comunidade a ser convertida. O American way of life é inevitavelmente proposto como modelo de vida: modos, estética, higiene, família nuclear, raça branca, tecnologias etc. Esta mensagem podia ser lida nas entrelinhas de afirmações retóricas recorrentes nos folhetos distribuídos nos cursos do SIL ministrados no Brasil, chamados significativamente de cursos de "Lingüística e Missiologia":

[...] deve-se considerar incerto, porém sempre crescente, o reconhecimento de que ou a civilização norte-americana une as suas forças às de outras civilizações inclusive a de povos menos privilegiados — ou nenhuma civilização poderá sobreviver por muito tempo (Kahn 1986, s/p).

Ouvir dos índios as palavras "Ele fala a nossa língua, é dos nossos" representaria o coroamento do moderno trabalho missionário. Como observa um dos sistematizadores da ideologia do SIL, o missionário deve ser capaz de conversar sobre os aspectos mais íntimos das crenças de seu rebanho para conseguir convencê-lo a aceitar princípios que conflitam com sua história e sua cultura.

Aprender uma língua é algo mais do que uma simples habilidade mecânica de reproduzir sinais acústicos como se fosse para conseguir vender uma mercadoria ou encontrar a via de saída. É um processo pelo qual nós fazemos contatos vitais com uma nova comunidade, uma nova maneira de viver e um novo sistema de pensamento. Conseguir isso da melhor maneira é o requisito básico da efetiva tarefa missionária (Nida 1957:8). 
A conjunção entre lingüística e missão é sacramentada e a questão da escrita de línguas indígenas torna-se o cerne de todo o sistema. Chegar ao estabelecimento de uma ortografia cientificamente correta pressupõe uma longa pesquisa de campo, com descrição e análise da língua em todos os seus níveis para que possa ser o instrumento da evangelização. A nova escrita imprime, afinal, a palavra de Deus e transforma-se no ponto de partida imprescindível para a alfabetização em programas educacionais sempre declinados segundo a filosofia oficial de cada governo. É a dupla conquista civilizatória.

Não meses, mas anos de pesquisa em campo são dedicados pelos missionários visando à instauração de uma grafia definitiva. A grafia "adequada" é sempre a psicofonêmica ou simplesmente fonêmica; nela, os símbolos, os grafemas, correspondem a unidades fonológicas (fonemas). Um segundo critério diz respeito à necessária adaptação à escrita da língua nacional; a escolha de grafemas é, assim, limitada pelos já existentes no alfabeto da língua nacional. Enfim, a língua indígena é instrumento para uma alfabetização-ponte cujo objetivo é facilitar a aprendizagem da língua dominante, transmitida por etapas, antes em sua forma oral, depois na própria escrita. ${ }^{7}$

Saber fonética e fonologia - aprendidas nos cursos de lingüística e missiologia - são pressupostos mínimos para essa tarefa. Além disso, o planejamento de uma ortografia deve considerar certo número de fatores chamados sociolingüísticos: dialetos, divisões religiosas, políticas, ortografias já existentes, faixas etárias, necessidades da impressão usando o alfabeto da língua nacional dominante. Por último, o sucesso de uma grafia depende da sua aceitação por alguns do grupo, que deveriam passar a usá-la sem grandes dificuldades até se tornar parte de sua cultura, nos termos do próprio SIL. A grafia é, então, a pura conversão - adequada, embora não perfeita - das unidades fonológicas reais da língua oral. Até aqui a tarefa parece ser apenas, diríamos, técnica, a de uma mera conversão de códigos cientificamente embasada. Há todo um processo que batiza a nova escrita, envolvendo tradutores e consulentes de tradução, os fiscais da escrita (Stoll 1982; Barros 1993). A aliança entre lingüista e tradutores coloca a escrita a serviço de uma outra tarefa, fortemente ideologizada e sutil instrumento de mudanças culturais e sociais.

Os Wapichana tinham recebido dos evangélicos uma grafia já elaborada e testada, mas na qual eles viam vários problemas. A ortografia evangélica começou a ser discutida e, aos poucos, foi sendo compreendido o seu arcabouço e os seus bastidores ao longo de seminários que fui chamada a organizar e a conduzir sobre a fonética e a fonologia dos Wapichana. Não obstante a sua roupagem eficiente e científica, permaneciam empecilhos 
intransponíveis à sua adoção: o sotaque estrangeiro e a identificação com um segmento missionário inimigo dos católicos que atuavam junto a boa parte dos Wapichana brasileiros.

O primeiro problema advinha do fato de que tal grafia tinha sido moldada segundo a escrita do inglês, língua oficial da Guiana, ex-colônia inglesa. A preocupação era evitar qualquer crítica "nacionalista", ${ }^{8}$ o que certamente poderia vir das agências educacionais do governo local (Roraima); a escrita deveria assim "aportuguesar-se", a fim de reforçar a proposta em gestação. O segundo problema decorria paradoxalmente do aspecto cientificamente mais sólido e convincente da "escrita evangélica": a "lógica" fonêmica, pela qual cada grafema ou letra representaria um fonema, unidade distintiva da estrutura que organiza a matéria sonora da língua.

A escrita fonêmica é historicamente uma conquista da lingüística moderna em prol da entrada das culturas de tradição exclusivamente oral no mundo letrado, já que significa a aplicação do conhecimento fonológico para o estabelecimento de um alfabeto e das outras normas ortográficas de uma língua. Em outras palavras, uma escrita fonêmica é pensada como natural, já que repousaria sobre o conhecimento lingüístico interno, não-consciente, do falante - conhecimento não apenas fonológico, mas integralmente gramatical. O processo que leva a uma escrita fonêmica implica, contudo, o exercício de um considerável grau de abstração e pressupõe a inevitável intervenção do lingüista. Uma vez consolidada a escrita fonêmica, seu sucesso na alfabetização seria conseqüência de sua "naturalidade", posto ser ela aceita pelos alfabetizandos, os falantes nativos da língua ortografada.

A aparentemente inexplicável rejeição da escrita puramente fonêmica pelos Wapichana - como por muitos outros povos indígenas - podia ser vista como a expressão da tensão entre duas "naturezas": de um lado, a já mencionada associação entre grafemas e fonemas; do outro, as convenções ortográficas do português percebidas como "naturais", sendo uma língua de prestígio que tem a escrita como parte integrante do seu existir e da sua força. Explica-se, assim, o desejo e o imperativo de adequar a norma escrita da língua indígena, recebida como algo inventado alhures e doado, à norma escrita da língua do branco. Os Wapichana eram obrigados, todavia, a lidar não somente com a escrita dos crentes, mas também com a dos missionários católicos. ${ }^{9}$

\section{A escrita dos católicos}

Entre a experiência registrada do encontro com as línguas indígenas nos primórdios da colônia e a recente abertura à filosofia da educação bilíngüe, 
um longo período dominado pelo aniquilamento da diversidade lingüística nativa marcou políticas e práticas das missões católicas. No contexto da revisão da tarefa missionária empreendida pela Igreja católica nos últimos anos, a preocupação dos católicos a respeito da implementação de uma nova perspectiva da educação bilíngüe começava a ocupar com bastante ênfase os veículos da Diocese de Roraima (Missão da Consolata), ora pela voz dos padres, ora pela voz atribuída aos próprios índios:

[...] é bom aprender o português para entender os brancos e não se deixar enganar por eles; mas de jeito nenhum podemos esquecer a nossa língua macuxi. Devemos defender o que é nosso e dar valor a tudo aquilo que os nossos pais nos ensinaram. Só assim podemos melhorar a nossa vida e defender melhor os nossos direitos. A língua macuxi é, para nós, uma arma que podemos utilizar para comunicar melhor entre nós e que, além de tudo, os brancos não compreendem [...] (Roraima Indígena, 83:15).

O livro Waparadan, apresentado como uma espécie de guia para a aprendizagem do wapichana, tinha sido o primeiro ensaio da grafia "católica", elaborada com a ajuda de assessores leigos da Missão, assessores estes com informação antropológica e lingüística bastante superficial. Tratava-se não tanto do resultado de um estudo lingüístico para a "ortografização" ou para a alfabetização em língua indígena, mas sim de um objeto cuja eficácia simbólica seria o incentivo para um resgate, ou melhor, a consagração de uma mudança no trabalho missionário. O livro, impresso e publicado, manifestou logo os problemas da nova escrita.

Havia vários equívocos lingüísticos na grafia criada. Tratava-se de uma mistura de registro fonético impreciso, de adaptação extremada à escrita do português, de erros devidos a um estudo superficial e apressado das estruturas da língua. Se os Wapichana não tivessem tido alguma experiência da escrita "evangélica", certamente não teriam notado outros e até maiores problemas da escrita "católica". Os índios percebiam claramente suas insuficiências e podiam criticá-las uma por uma. Era evidente a defasagem entre os evangélicos e os católicos quanto ao domínio das técnicas lingüísticas modernas: a grafia e a gramática "católicas" resultavam de um processo de simplificação ou transfiguração da língua indígena, através de um esquema a meio caminho entre a gramática prescritiva e as categorias clássicas da escolástica, as mesmas que tinham conformado, séculos antes, a descrição lingüística jesuítica.

Os missionários começaram a produzir material escrito em macuxi e, em menor quantidade, em wapichana. Além dos inevitáveis livros de cantos 
religiosos e da intenção de passar à tradução de textos para catequese, considerável trabalho foi dedicado à edição de livros de "histórias" indígenas acompanhados de comentários sobre o valor e o significado atribuídos a esse tipo de preservação e divulgação da memória oral:

Tentou-se escrever de uma forma diferente daquela escrita nos Evangelhos [...] Quando os brancos chegaram nas terras indígenas disseram que as histórias dos índios eram mentiras, bobagens sem valor. Assim, os índios acreditaram na palavra do branco [...] Por isso, (as histórias) desapareceram [...] As histórias dos índios foram chamadas de "mitos" [...] (Anna Maimu, Waparadan, 1981a, s/p).

O que são na verdade os mitos e as histórias dos índios? [...] Descrevem a vida dos antigos [...] Ensinam a ser esperto, a livrar-se dos mais fortes que querem pisar sobre os índios [...] Os mitos são uma arma que os índios utilizam para defender-se contra os brancos que querem que desapareçam ou virem civilizados [...] (Anna Maimu, Waparadan, 1981b, s/p).

Nos contos macuxi, a Onça representa o perigo, a ameaça do violento, do mais forte: o "civilizado opressor" que quer comer o Jabuti-índio, com terra, tradição, língua e tudo. As Onças representam os Violentos contra os quais os Jabutiíndios têm que lutar, com astúcia e sabedoria [...] As Onças da Nova Ditadura [...] Os Jabuti-índios têm só uma estratégia para vencer as Onças poderosas: unirem-se também e jogar contra eles as pedras das leis recém-aprovadas na Constituição [...] (Igreja a Caminho, 1988:5).

Os Wapichana contemplavam os livros de "literatura indígena": uns produzidos pelos católicos, outros pelos crentes, outros ainda por iniciativas vindas de órgãos do Estado. A presença de textos escritos em língua indígena consagraria a originalidade dessa "literatura", a grande maioria sendo em macuxi. Para os Macuxi, havia também uma escrita evangélica e uma escrita católica. Mesmo incorporando o discurso da autodeterminação, da "educação para a liberdade", contrapondo-o ao discurso da integração, os resultados do trabalho dedicado à edição de livros de histórias indígenas por parte da missão católica equivaliam aos produtos evangélicos. Tratava-se, enfim, de um mesmo tipo de "literatura". Apropriava-se de um saber (língua, narrativas) que, reelaborado drasticamente, era devolvido desfigurado aos seus produtores originais com uma reinterpretação imposta com autoridade incontestável. A crítica de Stoll (1982:256), dirigida à produção do Summer Institute of Linguistics, pode ser ampliada para incluir toda essa "literatura indígena": há um abismo que separa a sofisticação dos sistemas intelectuais 
indígenas da pobreza que caracteriza a grande maioria do material que se destinaria aos que sabem ler.

Para todos valia, em última instância, o que diz Kahn:

Diante da autoridade que a escrita assume para o índio, essa língua, construída e adaptada, pode passar a ser uma nova língua, a língua dos novos tempos. Para isso serve na atuação dos missionários a alfabetização na língua materna, que vem legitimar aquele procedimento. Aquilo que se ensina nas cartilhas extrapola a conversão dos sons em símbolos (grafia) e cria textos que, "adaptados" ao universo simbólico do grupo, vão na verdade criar uma nova língua, uma nova fórmula de vivenciarem e expressarem sua vida [...] Cria-se, portanto, com a "língua falada na escola", uma nova categoria, um novo padrão de comunicação. Só que quem cria esse novo padrão são os profissionais da linguagem de Deus, os agentes da civilização e da "iluminação". É na figura do professor-missionário da aldeia que se garantirá o repasse de uma ideologia da sociedade ocidental, cristã, em busca da salvação (Kahn 1986, s/p).

A escrita era essa nova "língua", meio de conversão ao mesmo tempo religiosa, social e política, difundida pelo Ocidente e imposta para cumprir, custasse o que custasse, sua missão civilizatória, nivelando e limitando a expressão das formas da oralidade.

Poder-se-ia aplicar a esse encontro de culturas da oralidade em desagregação com o universo da escrita os conceitos de "código restrito" e "código elaborado" propostos pelos sociolingüistas. Temos aqui uma espécie de inversão dos contextos encontrados entre os segmentos marginais das grandes cidades: para as sociedades indígenas, com a oficialização do código restrito de uma expressão escrita monitorada, o que se perde é o código elaborado das artes verbais da tradição oral. Nessa passagem da oralidade à escrita, contrastam os tratamentos dados, por um lado, às histórias indígenas, narrativas tradicionais e, por outro lado, às histórias dos textos cristãos. Às primeiras se aplica uma operação de redução, que redunda em empobrecimento; às segundas se aplica, ao contrário, uma operação de tradução fiel, com todos os cuidados da exegese e da transposição por equivalências sintáticas e semânticas. O resultado acaba contradizendo e desmistificando a retórica do refrão "escrita a serviço do resgate". Os índios leitores elaboram rapidamente uma comparação entre seus mitos espremidos e banalizados - um folclore de pequenas ficções - e os grandes mitos dos brancos consagrados em livros verdadeiros. Enfim, aos primeiros se destinam o código restrito da chamada "literatura indígena" e o termo "mito" com as conotações negativas do senso comum; aos segundos se destina o código 
elaborado de uma "estória-história verdadeira", cuidadosamente distinta dos gêneros literário e mítico.

Os Wapichana começavam a arranhar a superfície das retóricas evangélica e católica e, ao mesmo tempo, com os outros atores no palco, iam se apropriando do duplo e dúbio discurso da civilização e do resgate graças à educação bilíngüe.

\section{Os Wapichana querem escrever}

Nem a escrita dos missionários evangélicos nem a dos missionários católicos, com toda a sua força ideológica explícita, deixaram os Wapichana satisfeitos. Retomemos a questão com as lembranças escritas em seu diário por um professor wapichana, então diretor da escola da Malacaxeta, lembranças estas que se iniciam pelo tempo transcorrido em um internato católico:

Foi aí que comecei a sentir os primeiros problemas com as dificuldades na escrita, pois tinha um livro chamado Wapishana primer [a cartilha dos evangélicos da Guiana], que tinha tudo escrito, só que para mim estava tudo errado e eu não entendia nada e agora como faria para dar aula uma vez que seria eu quem daria aula de wapichana [...] Foi aí que tive uma idéia de escrever como escutava o som das palavras [...] mas mesmo sem saber por que e como fazer continuei a escrever como escutava o som e deixei o livro de lado e fui escrevendo como achava melhor [...] Todas as vezes que escrevia surgiam mais dúvidas e sempre perguntava a mim mesmo se estava certo [...] Sem saída fui obrigado a usar o livro que para mim estava errado, por outro lado valeu pois o livro estava pronto do jeito de ensinar e aprender uma língua. Foi aí que começamos a montar o esqueleto da escrita da língua wapichana. Fomos modificando muitas coisas da nossa escrita até que fizemos um livro com o nome de Wapichana paradan, ou seja, Waparadan, que significa "nossas palavras" ou "nossa fala". Partindo daí se pensou que não estava nem um pouco correto a escrita na nossa língua e começamos a pesquisar qual seria o certo [...]

O mesmo professor, ao comentar essas lembranças, me dizia algo já ouvido por mim de muitos outros índios: "Sempre fiquei com a impressão de que essas nossas línguas são duras, até impossíveis de serem escritas direito". As peripécias vividas na passagem e na oscilação de uma ortografia para outra, na busca do "certo" atravessando disputas religiosas e nacionais, produziam um forte sentimento de inferioridade, reforçado pela representação do português como uma língua naturalmente dotada de escrita. 
De início, percebi que o problema da "fidelidade gráfica" — a adequação funcional da ortografia vista como transcrição da fonêmica de uma língua era considerado pelos índios mais uma marca da escrita "evangélica da Guiana" do que uma qualidade independente de contexto. Cardona relata um quadro muito semelhante ao tratar da história da "ortografização" das línguas na África, mostrando como a introdução da escrita acompanha a entrada das populações autóctones no mundo colonial:

Mais do que qualquer consideração pedagógica ou técnica sobre a utilidade dos vários sistemas, contam as afiliações políticas e religiosas instituídas por cada sistema [...] O luganda é a primeira língua para milhões de falantes em Uganda e a segunda pelo menos para outros 3 milhões; por volta da metade do século XIX, os primeiros contatos com os árabes provenientes do litoral, que falavam árabe ou swahili (língua bantu como o luganda), levaram à islamização do país e à adoção, junto com a religião, da escrita árabe ou árabo-swahili. Em 1878, porém, com a evangelização, ao mesmo tempo e independentemente, foram introduzidos no país por missionários protestantes ingleses e católicos franceses dois sistemas ortográficos de base latina, semelhantes mas distintos. Os dois sistemas, que correspondiam a duas diferentes afiliações religiosas e políticas, se sobrepuseram à situação de conflito do país, dividido em fiéis do rei, favoráveis às missões católicas, e anti-realistas, de educação protestante. Assim, as escolhas gráficas explicitavam de imediato o tipo de educação e as adesões políticas de quem escrevia; daí a necessidade de encontrar um sistema de compromisso que, unificando os dois sistemas, garantisse o anonimato dos que escreviam. Após duas reuniões (1944 e 1947), escolheu-se finalmente uma grafia unificada, mas as resistências continuaram por muito tempo, com conflitos até graves [...] (Cardona 1981:125, tradução minha).

Ao administrarem, entre outras coisas, a referência evangélica, a influência dos missionários católicos e as pressões do Estado, os Wapichana de Malacaxeta queriam na verdade uma nova escrita que se distanciasse, nos limites do possível, das propostas existentes, procedendo a um experimento de confronto crítico entre elas e a uma espécie de bricolage de grafemas. Em sucessivas reuniões lideradas pelos chamados "mestres da língua" — alguns dos últimos falantes fluentes do wapichana - as diferentes escritas foram objeto de análise e iniciou-se um processo de "descoberta" das estruturas da língua. Presenciei vários ensaios ortográficos, até chegar a uma grafia que, se não definitiva, era pelo menos o resultado de uma discussão coletiva, grafia que assim podia gerar a cartilha oficial prometida pelas autoridades e às autoridades. 
Foi o processo dessa discussão o aspecto mais interessante da "criação ortográfica" empreendida pelos Wapichana, independentemente das conseqüências - sucesso ou fracasso — de sua aplicação a um projeto de resgate lingüístico. Um exemplo pode ilustrar melhor o confronto e o desenvolvimento das grafias, bem como o redemoinho de letras e alfabetos em que os Wapichana foram sugados. No quadro abaixo, compare-se a escrita de algumas palavras wapichana nas diferentes ortografias, que serão comentadas a seguir: a dos crentes, a dos católicos, a dos Wapichana em seu primeiro ensaio autônomo (Wap) e, finalmente, a sucessão e as soluções propostas ao longo da elaboração da cartilha oficial.

\begin{tabular}{|l|l|l|l|l|}
\hline & Crentes & Católicos & Wap & Cartilha \\
\hline "fogo" & tikaz & tikier & tiquierr & tikier, tikiez \\
\hline "banana" & suuz & ser & sir & sur, sir, syz, syyz \\
\hline "sapo" & kibaro & kibero & quibiaru & kibiero, kibieru \\
\hline "cobra" & koazaz & kuarrarra & cuarrarra & kuarara, koarara, kuazaz \\
\hline "tatu" & kapashi & kapaxe & capache & kapaxi \\
\hline
\end{tabular}

Observe-se como a grafia (Wap), criada inicialmente de forma autônoma pelos Wapichana, distingue-se das demais. Em primeiro lugar, está nela contida a preocupação com um "aportuguesamento" radical, que se reflete em exclusões e escolhas. Se há variedades orais que gozam de um prestígio maior do que outras para aqueles que as falam, e sobretudo para aqueles que não as falam, o mesmo pode se dizer das variedades escritas. Como diz Cardona:

A programação de ortografias para as línguas ágrafas defronta-se com evidentes julgamentos de prestígio. Nas ex-colônias gozam de grande influência as ortografias (e não só as línguas) dos colonizadores [...] É óbvio que tal homenagem ao prestígio dos colonizadores tem certas desvantagens. Onde é falada uma mesma língua, em países de influências diferentes [...] introduz-se um motivo de divisão puramente externo, que impede de unificar os materiais impressos [...] Quem aprende a ler e a escrever, ao invés de poder servir-se de uma ortografia que reflita de maneira funcional a sua língua, deve fazer as contas com um sistema que se originou e se desenvolveu alhures [...] (Cardona 1981:122, tradução minha). 
Os grafemas "estrangeiros" $|\mathrm{k}|^{10},<\mathrm{sh}>$, presentes na grafia do wapichana falado na Guiana, foram cuidadosamente eliminados e substituídos por $|\mathrm{c}|$ ou $|\mathrm{qu}| \mathrm{e}|\mathrm{ch}|$, respectivamente, incorporando dessa maneira os problemas da grafia do português ( $|\mathrm{c}|$ e $|q u|$ para o mesmo som/fonema, como em "quina" e "cobra"). ${ }^{11}$ A consoante fricativa palatal, representada por $|\mathrm{sh}|$ do lado guianês, poderia ter sido grafada com a letra $|\mathrm{x}|$, mas sua raridade no português escrito foi interpretada como estrangeirismo, fazendo dela uma má alternativa. Por outro lado, o dígrafo |ch| apresentava-se, por analogia com a sua forma visual, como um bom correspondente brasileiro do dígrafo "inglês" | sh|. A representação da fricativa retroflexa, som peculiar do wapichana, era objeto de uma preocupação particular: a letra $|z|$ foi evitada, porque considerada, ela também, "esquisita", rara ou marginal na escrita da língua nacional; em seu lugar apareceu o dígrafo |rr|. De novo, havia um esforço de aproximação com a intuição fonética, já que o |rr| grafa uma fricativa do português (velar ou glotal, dependendo do dialeto), mas perdendo em precisão fonética (o ponto de articulação álveo-palatal e a retroflexão da fricativa wapichana).

A forte referência ao alfabeto português fez com que desaparecesse por completo a vogal central fechada do wapichana; um único grafema - $|\mathrm{i}|$ foi utilizado para expressar dois sons com valores distintivos próprios, já que em wapichana há também a vogal [i], igualmente fechada, mas anterior. Assim, a inexistência do som na língua nacional condenou à inexistência um elemento estrutural da língua indígena. ${ }^{12}$ Note-se também, nessa versão ortográfica, uma oscilação significativa entre a percepção do sistema fonêmico e a sensibilidade a variações puramente fonéticas, cuja realização ortográfica é fortemente determinada pela orientação a partir da escrita do português. São representados, desse modo, a alternância entre [u] e [o], as manifestações fonéticas de um mesmo fonema (kibiaru, kibiaro) e o resultado de processos de palatalização, como a da consoante que segue a vogal [i], com a concomitante mudança de [a] para [e]: kibaro, na escrita consistentemente fonêmica, torna-se kibieru ou kibiaru ou kibiaro: ([b] realiza-se como $\left[b^{\mathrm{y}}\right]$ e [a] como [e], após a vogal [i]) .

Ao longo da discussão sobre as diferentes grafias com os Wapichana da escola de Malacaxeta, os índios avaliaram a exatidão fonêmica da grafia dos evangélicos, bem como a simplificação empobrecedora da grafia dos católicos e os problemas herdados desta última nos primeiros escritos produzidos autonomamente por alguns Wapichana. O processo foi demorado e pontuado por delicadas análises, até chegar à grafia que se queria apresentar como "nova". A insegurança diante da necessidade de aceitar um distanciamento do parâmetro do português e de introduzir símbolos "estranhos" foi aos 
poucos substituída por uma identificação emblemática entre a distintividade do wapichana como "língua verdadeira" e não como "gíria" e os seus sons "diferentes": sons retroflexos, vogais articuladas em outro espaço da cavidade oral, um leque de fricativas. A partir desse momento, voltaram ao alfabeto wapichana o $|\mathrm{k}|$, o $|\mathrm{w}|$, o $|\mathrm{x}|$, o $|\mathrm{z}|$. Como, por exemplo, grafar aquela vogal central? A sucessão dos seus símbolos ortográficos é também significativa. É rejeitado o $|\mathrm{u}|$ dos evangélicos, por se confundir com outra vogal do português, o |i | usado em macuxi para o mesmo som, por não marcar uma distinção étnica importante. Propõe-se, afinal, outro grafema $|\mathrm{y}|$ - aceito sem grande preocupação agora, apesar de ser um símbolo outrora considerado "estrangeiro".

A discussão caracterizou-se por duas tendências concomitantes, mas contraditórias, para o rigor de um lingüista: de um lado, o desenvolvimento de uma sensibilidade às peculiaridades fonéticas e fonológicas do wapichana; do outro, a rejeição da abstração da escrita puramente fonêmica dos evangélicos. Assim, chegou-se a registrar com cuidado as vogais longas, fonêmicas, (syz, syyz), e a oclusiva glotal, outro fonema do wapichana. Ao mesmo tempo, porém, deixou-se à "nova" grafia uma margem de liberdade para a fidelidade fonética, distinguindo-a, desse modo, da escrita "lógica" dos lingüistas missionários norte-americanos. Decidiu-se manter, assim, as variantes [u] e [o] e os resultados perceptíveis dos processos de palatalização.

Com a nova escrita elaborou-se uma cartilha, e deixei finalmente Roraima e os professores wapichana às vésperas de uma experiência arriscada e cujo desfecho era imprevisível: ensinar nas escolas de maloca a língua materna de pais e avós de alunos falantes do português e alfabetizados em português. Nossas reuniões de trabalho foram um verdadeiro estudo das estruturas da língua e da história de cada grafia existente; a nova grafia foi o produto de sucessivas e diferentes avaliações da natureza do código escrito. Uma vez encaminhado um processo em que a discussão sobre a escrita acabou se tornando o eixo de uma reflexão sobre a escola, a crise, as saídas, os poderes e a diversidade lingüística, não era fácil prever a direção da experiência iniciada.

Os Wapichana de Malacaxeta viviam o dilema da precariedade do caminho da autonomia e das barganhas que condicionavam a concessão do apoio oficial. Enquanto isso, os velhos "mestres da língua" não eram reconhecidos como profissionais da educação formal e, num clima de desconfiança, cartilhas e outros "livros" que podiam vir a ser produzidos pelos índios eram vistos como uma ameaça por serem produtos que escapavam do crivo oficial, governamental ou missionário. Por último, era impossível prever as dificuldades e os equívocos da implementação de um ensino do 
wapichana como segunda língua, ou mesmo da alfabetização na língua indígena, inseridos em um contexto complexo de crise lingüística.

Com sua "nova" escrita, os Wapichana estavam numa encruzilhada e presos a um paradoxo. Algumas conclusões podiam ser delineadas a partir das experiências passadas; para o futuro, as hipóteses plausíveis dependiam de saídas de uma problemática cheia de contradições. Qual encruzilhada e qual paradoxo? A nova escrita não deixava de ser mais uma versão da escrita da "civilização", da integração; por si só, ela era também um veículo da nova língua que surgia da palavra reificada pela tecnologia ortográfica. Ela vinha, assim, somar-se a todos os passos que desde a "invenção" da escrita transformam as culturas tradicionais da oralidade. No encontro histórico entre oralidade e escrita, há perdas e aquisições, ambas definitivas. Ainda resta fazer um acompanhamento crítico dessas transformações lá onde elas estão acontecendo, ou seja, onde são ainda testemunhadas as primeiras fases desse encontro.

Costuma-se menosprezar a necessidade de uma perspectiva crítica diante da adesão mais ou menos imediata à ideologia difusa que comunga missão civilizatória e propósitos de "resgate" cultural e lingüístico através da educação e da escrita. No caso da língua wapichana, é de se perguntar o significado real desse "resgate", palavra de ordem nas bocas de todos: índios, missionários e agentes do Estado. Recuperar, salvar, preservar que língua, que tradições? O que é o wapichana depois da longa crise que o asfixiou e de sua transfiguração nas várias ortografias? Que operação de salvamento é essa reificação dos "mitos" em historinhas de sabor infantil? Quais as conseqüências, um tanto imprevisíveis, do projeto de ensinar a língua indígena como segunda língua no espaço disciplinar da escola formal?

Qual é, afinal, o significado dessa "operação de resgate" uma vez metabolizada como retórica de aparência pelos programas de "educação para índios" financiados pelo Estado? Os Wapichana de Malacaxeta tentaram uma dupla estratégia, num difícil equilíbrio. Quiseram incluir-se sem demora nos planos oficiais de publicação de cartilhas - primeiro passo de um programa amplo de implementação da educação bilíngüe — para consagrar publicamente sua nova escrita e, com isso, anunciar uma língua ressuscitada na terra queimada da assimilação lingüística.

\section{Os Kuikuro na dança das letras}

Falta uma etnografia das experiências, continuadas ou soluçantes, da escrita nas sociedades indígenas. Eu não dediquei a mesma atenção ao caso Wa- 
pichana, que encontrei quase que episodicamente, e ao caso Kuikuro, ${ }_{1}^{13}$ por cuja língua e vida me interesso há trinta anos. Fui protagonista, autoridade responsável, pela gênese da que se pode chamar hoje escrita da língua karib do Alto Xingu, uma história bem diferente daquela que vimos se desenrolar para os Wapichana, uma história aparentemente mais tranqüila, já que o Alto Xingu foi, até muito recentemente, um território proibido aos missionários. Seria este um terreno virgem para um exercício sereno da lingüística aplicada ou para uma descoberta sem trauma da escrita pelos índios?

A experiência da exposição à escrita existia antes de eu chegar como lingüista e pesquisador e alfabetizar rudimentarmente um jovem em reclusão pubertária em $1981 .{ }^{14} \mathrm{E}$ continuou, cada vez mais intensamente, entre um e outro dos meus períodos de pesquisa de campo. Dentre os primeiros encontros dos Kuikuro com a escrita de suas palavras, sem dúvida o mais marcante é o da grafia dos nomes próprios em fichas médicas e documentos, aos poucos apropriada para assinaturas, aparecendo em bilhetes, esculpida em casca de árvore ou pedaços de madeira, pintada em postes e portas. Os nomes dos Kuikuro surgem grafados de várias maneiras distintas e cada uma delas implicando alguma "surdez" do branco.

O som correspondente a uma vogal inexistente em português — a vogal alta central/ posterior, representada pelo símbolo [i] do Alfabeto Fonético Internacional (IPA) - tem sido grafado ora como $u$ ora como $i$, negando assim a sua distintividade ao assimilá-lo ora a uma, ora a outra das vogais altas do português, ou ainda, mais raramente, com $|\mathrm{y}|$, transferindo o símbolo usado quase tradicionalmente para o mesmo som em ortografias de línguas tupi-guarani. Ao "descobrirem" essa vogal, os jovens alfabetizandos karib atribuíram mais tarde a ela o |ü|, uma invenção, um bricolage de elementos visuais, para nomear graficamente esse som, fazendo-o distinto das outras vogais altas $(i, u)$ presentes na língua indígena e no português, mas não tão distinto quanto a letra $|\mathrm{y}|$ do vizinho kamayurá, cujos falantes se viam compelidos a seguir a tradição da escrita das línguas tupi-guarani. Veja-se, à guisa de exemplo, as diferentes grafias do nome de uma mulher kuikuro. A primeira grafia é a transcrição feita pelo lingüista utilizando o IPA, e serve aqui como referência:

$$
\text { Młsé Musé Misé Mysé Müsé }
$$

Diferentes grafias dos nomes próprios se mantêm concomitantes, oscilando e incluindo a ortografia atual (Müsé) usada por detentores da escrita em kuikuro, professores e alunos da escola da aldeia. Conflitam hoje a existência de uma "norma", de um "jeito de escrever correto" do ponto de 
vista dos que passaram pela formação escolar, e a de grafias "erradas", mas imobilizadas nos documentos oficiais que cumprem a função de identificar indivíduos perante as instituições do Estado voltadas para a assistência à saúde e ao fornecimento de serviços e bens, dos quais os índios estão cada vez mais dependentes.

A isto se deve acrescentar outro aspecto dessa imobilização do nome próprio. Nas sociedades alto-xinguanas, o indivíduo recebe dois estoques de nomes, um pelo lado materno, outro pelo lado paterno, mudando seus nomes (para o plural) ao ingressar em cada novo ciclo de vida: infância, iniciação pubertária, nascimento do primeiro filho e do primeiro neto. Assim, documentos e fichas perpetuam indelevelmente apenas uma fase da identidade de cada pessoa, dependendo do momento em que seu nome foi inscrito definitivamente na lógica da identificação do mundo dos brancos. Mesmo numa situação, como a dos índios alto-xinguanos, em que nenhuma igreja passou batizando, acrescentar e assumir um nome "caraíba" (de branco) torna-se uma solução para evitar o mal-estar vivenciado nas ocasiões de confronto entre as duas lógicas da nomeação. O próprio etnônimo "Kuikuro", com o qual essa população ficou conhecida, encerra em sua grafia uma história densa de sentidos:

\section{Kuhikuru Cuicutl Cuicuru Cuicuro Kuikuru Kuikuro Kuhikugu}

No final do século XIX, o etnólogo alemão Karl von den Steinen registrava entre os vários povos das margens do rio Culuene a existência dos Guikuru ou Puikuru ou Cuicutl (Steinen 1940 [1894]). Steinen observava a dificuldade de representar um som distintivo e particular, mas muito comum, das línguas karib alto-xinguanas. Trata-se de um tepe uvular, percebido às vezes como fricativa velar vozeada ou como oclusiva velar vozeada, sendo registrado por ouvidos não-treinados como uma oclusiva velar vozeada [g] ou um tepe alveolar [r]. Não há ainda um símbolo específico para o tepe uvular no Alfabeto Fonético Internacional, de modo que convencionamos representá-lo provisoriamente com o símbolo da fricativa velar vozeada [४]. De fato, o nome que Steinen ouvia e tentava registrar era Kuhikuðu, o grupo local que naquela época habitava a área kuhikưu, uma contração de kuhi

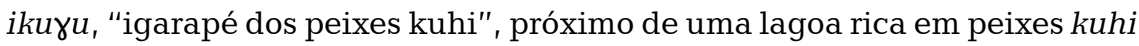
(Potamorraphis, fam. Belonidae). Os de Kuhikuyu constituíram a primeira aldeia de um novo grupo local (ótomo, na língua kuikuro) que se separou dos outros grupos locais karib do Alto Xingu provavelmente antes de meados do século XIX; foram eles os fundadores de um povo que os brancos chamam até hoje de Kuikuro, mas que ainda se autodenominam de Lahatuá ótomo, 
do nome da aldeia forçosamente abandonada após a epidemia de sarampo de 1954, que dizimou metade da sua população.

Steinen mostrava-se intrigado com a qualidade fonética do tepe uvular e conseguiu descrevê-lo com precisão, chegando a propor para ele um símbolo do alfabeto grego, o lambda, ou o dígrafo |tl|. A peculiaridade desse som condenou-o a ser representado, depois de Steinen e até hoje, pelo grafema $|r|$ e foi trabalhoso e quase dramático o processo pelo qual passaram os professores kuikuro até chegarem ao reconhecimento de sua especificidade e o início da busca de uma representação ortográfica, digamos, "adequada". Como sempre no fio da navalha, entre o reconhecimento de uma "realidade específica" e o desejo de evitar marcas de diferença excessiva, sobretudo do português enquanto referência normatizadora, os jovens "donos da escrita" optaram finalmente pelo $|\mathrm{g}|$, um compromisso entre o registro da sua qualidade articulatória e uma letra do alfabeto. A deformação do nome Kuhikugu ótomo - antigo e ancestral — cristalizou-se como o nome coletivo dos seus descendentes e o sobrenome individual de cada um deles: para os brancos, Kuikuro.

Mais um exemplo ilustra outro caso, agora o da grafia de uma palavra que é nome próprio e nome comum ("pimenta"):

$$
\text { фomi Fomi Homi }
$$

Na língua kuikuro há uma alternância entre dois sons, as fricativas bilabial [ф] e glotal [h], sendo elas indicativas de uma variação geracional e posicional. O uso do $|\mathrm{f}|$ procura aproximar-se da primeira variante, utilizada pelos mais velhos, característica da "fala bonita" dos discursos formais tradicionais. O uso hoje dominante na escrita dos escolarizados é o da letra $|\mathrm{h}|$, representando a variante dos mais jovens e condenando a primeira ao desaparecimento na norma que quer se impor como "correta".

O alfabeto, decorado e declamado na escola, apresentado na primeira página das cartilhas, é um objeto intocável em sua quase-sacralidade, com sua lista de letras em ordem perfeita; a escrita, mais uma vez, não deixou de ser vista como parte constituinte da língua do caraíba. ${ }^{15}$ Após esgotar todas as possibilidades de associação de certos sons da língua indígena a uma ou outra das letras existentes, e assumidas certas decisões sempre com a vontade de declará-las como definitivas, onde colocar as novas letras como os dígrafos ou os trígrafos?

As decisões ortográficas foram sendo tomadas nas conversas entre professores e entre professores e o lingüista-assessor, não sem ansiedade, numa espécie de cálculo que ponderasse alternativas permitidas, os limites 
da intervenção possível no alfabeto, as explicações do lingüista, o aflorar de uma consciência metalingüística que a escrita ia conformando. Assim, tendo já o $|\mathrm{g}|$, a nasal velar foi representada pelo dígrafo $|\mathrm{ng}|$; tendo $|\mathrm{g}|$ e $|\mathrm{ng}|$, a oclusiva vozeada pré-nasalisada gerou um trígrafo $|\mathrm{nkg}|,{ }^{16}$ símbolo bastante complexo e difícil, certamente menos para os falantes nativos do que para os não-nativos. Vejam-se as grafias sucessivas e concomitantes de outro nome próprio e os termos para "chocalho (maraca)" e para um ritual mais conhecido na literatura etnológica como "tawarawanã":

$\begin{array}{llllll}\text { Oni } & \text { Oni } & \text { Ogi } & \text { Ongi } & & \\ \tilde{a}^{n} k e & \text { anke } & \text { ange } & \text { ãke } & \text { ãge } & \text { angke } \\ { }^{n} \text { tuhe } & \text { ntuhe } & \text { nduhe } & \text { duhe } & & \end{array}$

E como fixar a nasalidade ou o alongamento vocálico, resultante de ajustamentos prosódicos e fonológicos bastante complexos? A matéria sonora escapava a todo o momento da captura ortográfica; o problema resolvido agora iria retornar em seguida. Toda oscilação era interpretada como sintoma não do hiato entre oral e escrito, mas sim da incapacidade dos "escritores" ou da natureza da língua indígena. ${ }^{17}$ Assim, em pouco tempo, a expressão "nossa língua é pobre" foi substituída por "nossa língua é difícil", mais um preconceito absorvido no contato com os brancos, sua língua e sua escrita. Passava-se da atribuição da "pobreza" (simplicidade, primitivismo etc.) à da "dificuldade", algo aparentemente contraditório dito por um falante de sua própria língua materna. Afinal, como já disse alhures (Franchetto 1995, 2000, 2001), a "ortografização" da língua nativa, mais do que uma "conquista" - processo marcado por sentimentos de desânimo e frustração que, se não fossem os imperativos vindos do exterior, os da "educação bilíngüe" como passe obrigatório para a educação escolar — teria conduzido muito provavelmente à desistência de se "escrever na língua". Gênese e impacto da escrita aproximam assim, significativamente, dois povos tão distintos pela língua, pela cultura e pela história, como Wapichana e Kuikuro.

\section{Conclusões}

No Brasil de hoje as escolas de aldeia proliferam, assim como os cursos de formação de professores indígenas e a publicação e a circulação de materiais didáticos (cartilhas, livros) em língua indígena ou bilíngües, tudo conforme diretrizes oficiais que se apresentam como a definitiva implantação da educação bilíngüe, intercultural, específica e diferenciada. Não obstante, experiências 
como as dos Wapichana e dos Kuikuro continuam existindo, multiplicando-se na medida exata da disseminação, induzida ou não, de práticas e propostas de escritas em língua indígena. Os agentes educacionais, governamentais ou não, procuram a estandardização e a "nacionalização", motivados por imperativos pragmáticos, ignorando e aniquilando diferenças dialetais e características estruturais das línguas, mas não hesitam em produzir e usar várias ortografias para uma mesma língua quando o que está em jogo é a disputa para o controle de projetos, financiamentos, almas, territórios. Os índios ainda observam perplexos as danças das letras, ou por elas são levados.

A arena das ideologias em confronto, onde os índios do mundo letrado são atores ou vítimas, inclui ainda as polêmicas entre os lingüistas assessores. É compreensível o esforço despendido hoje por muitos lingüistas não-missionários que trabalham com línguas indígenas (foi até inventada a expressão "lingüística indígena") para apagar o legado missionário em sua vertente evangélica, afastando-se dele de modos variados e, às vezes, contrastantes. Há os que acusam a lingüística americanista de ser a portadora da ditadura fonêmica e subjacentemente grafocêntrica, apesar de se declarar voltada para a documentação de línguas orais e declarar a supremacia da oralidade como objeto de apreensão científica (Barros 1993). Há os partidários do processo da "escrita espontânea", não-monitorada por critérios que se apresentam como científicos, que sublinham a historicidade da escrita e o papel dos índios como atores/ usuários que navegam criativamente de um sistema a outro, quando vários sistemas de escrita se sucedem ou são concomitantes para uma mesma língua/ etnia. Os partidários da espontaneidade — "Escrevam! Escrevam de qualquer maneira, certo ou errado, não importa!" - estão convictos de que é imperativo, e primordial, mergulhar na escrita como se se tratasse de um banho restaurador, para fazê-la instrumento de uma expressão imediata e integral. "Fazer lingüística", aplicando conhecimentos acadêmicos ou científicos na gênese de uma escrita, é algo condenado como exercício autoritário e colonialista.

Do lado oposto está um punhado de lingüistas empenhados numa crítica severa às operações de domesticação através da "ortografização" de línguas indígenas — nacionalização, estandardização, escolha de línguas francas ou de alfabetização, apagamento de traços incômodos da matéria sonora - em prol de uma aplicação competente, mas não ingênua, dos conhecimentos científicos, contando-se com o envolvimento dos índios, ao mesmo tempo como docentes e discentes do saber lingüístico. Aqui, o respeito às línguas nos projetos chamados de "educacionais" se dá pela construção de um conhecimento e de uma consciência que procede em paralelo tanto no lingüista quanto no falante, posição defendida, por exemplo, por Gomez-Imbert: 
Uma "boa" escrita, para o lingüista, depende de um estudo competente da língua, da participação nativa nesse estudo, da compreensão do que é uma escrita, do estabelecimento (conjunto) de uma escrita fonológica, evitando eleger línguas francas ou de alfabetização em detrimento de línguas minoritárias e "fracas", destinadas de qualquer maneira ao desaparecimento [...] A prática generalizada é ensinar a falar, ler e escrever simultaneamente em espanhol (ou português) para crianças que não entendem, com o resultado de frustração, autocomiseração, auto-inferiorização, evasão e fracasso escolar, reforço dos estereótipos internos e externos [...] a minha convicção como lingüista é que se o sistema ortográfico que as crianças aprendem primeiro para sua primeira língua estabelece uma relação coerente entre o código escrito e o conhecimento implícito (internalizado) das crianças relativo à sua própria língua, a tarefa de aprender a ler e a escrever seria mais simples [...] (Gomez-Imbert 1998, s/p).

Nesta perspectiva, acredita-se que certos efeitos das tecnologias da palavra trazidas pelos brancos devem ser explicitados e redirecionados de modo a torná-los objeto de apreensão consciente. ${ }^{18}$

Os Xavante de Mato Grosso se dividem entre o $|\mathrm{t}|$ e o $|\mathrm{ts}|$ dos missionários evangélicos do SIL e o $|\mathrm{d}|$ e $|\mathrm{dz}|$ dos salesianos: os primeiros, fiéis ao princípio da escrita fonológica; os segundos, ignaros (ou tolerantes) em relação à realização fonética de unidades fonológicas. Um professor xavante, candidato ao primeiro curso universitário para índios, disse-me uma vez: "O que está por trás disso? Estou aqui querendo estudar mais para ter a resposta".

Línguas tonais correm sempre o risco de perder os seus tons, elementos sonoros tão distintivos como os segmentos representados pelas letras, porque a escrita alfabética não suporta o caos visual criado pela superposição de diacríticos "exóticos". A "ortografização" torna-se assim o crivo de consagração do que ela permite, ou de condenação de partes vitais de uma língua. Dizem certos lingüistas que este filtro da escrita é inócuo: as estruturas sonoras permanecerão operantes enquanto existir o conhecimento íntegro da língua. Será que sabemos o bastante para desconsiderar a interferência da experiência da escrita na oralidade, os tempos de sua inoculação?

Recebido em 06 de novembro de 2007

Aprovado em 21 de janeiro de 2008

Bruna Franchetto é professora do Programa de Pós-Graduação em Antropologia Social (PPGAS/ MN/ UFRJ). E-mail: bfranchetto@yahoo.com.br 


\section{Notas}

${ }^{1} \mathrm{O}$ termo "maloca" faz parte do vocabulário português local para referir-se às aldeias dos povos indígenas do lavrado roraimense (Macuxi, Taurepang e Wapichana) às vezes verdadeiras vilas rurais.

${ }^{2} \mathrm{O}$ trabalho se realizou nas malocas de Boca da Mata e Bananal (Taurepáng, município de Boa Vista), Napoleão (Macuxi, município de Normandia), Taba Lascada e Malacaxeta (Wapichana, município de Bonfim).

${ }^{3}$ Os termos "caboclo" e "civilizado" referem-se aos habitantes das malocas do lavrado (Macuxi, Taurepáng, Wapichana), considerados "aculturados", e aos não-índios, respectivamente. Os dois termos compõem uma tríade de categorias com outro termo - "índio" - usado tão somente para os Yanomami, "selvagens do mato" das montanhas ocidentais.

${ }^{4}$ Os Wapichana eram na época, segundo as estimativas do Instituto Socioambiental, 6.500 no Brasil (Roraima) e 4.000 na Guiana (Ricardo 2000).

${ }^{5}$ Após uma primeira passagem de missionários ingleses em meados do século XIX e o importante culto do Aleluia, movimento religioso que se difundiu a partir das missões anglicanas da Guiana no último quarto do século XIX, a Unevangelized Field Mission entrou no Brasil em 1968, vindo também da Guiana onde atuava desde 1950. A partir dos anos 40, a Baptist Mid-Mission, os Adventistas do Sétimo Dia e os Pentecostais ganharam influência considerável, sendo que se destaca atualmente a penetração da MEVA (Missão Evangélica da Amazônia ou Igreja Batista Regular) e da Assembléia de Deus. Várias igrejas evangélicas atuam entre os índios de lavrado de Roraima, mas as missões envolvidas com pesquisas lingüísticas e práticas educacionais são a MEVA (Missão Evangélica da Amazônia), a MNTB (Missão Novas Tribos do Brasil), a MICEB (Missão Cristã Evangélica do Brasil) e a Unevangelized Field Mission, na Guiana. Todas elas constituem uma espécie de constelação cujo centro gravitacional é o SIL, sigla do Summer Institute of Linguistics, hoje rebatizado, em sua versão brasileira, de Sociedade Internacional de Lingüística. A MEVA, com sua sede em Boa Vista, capital de Roraima, é o ponto de referência para os evangélicos que atuam na região; o SIL é a instituição mais poderosa e desenvolvida no Brasil no fornecimento do apoio logístico para as outras missões no que concerne a técnicas, ao preparo científico e ao treinamento regular dos agentes que se destinam ao trabalho de conversão e de pesquisa lingüística nas áreas indígenas. Trata-se, de fato, de uma complexa rede missionária que tem seus financiadores e mentores nos Estados Unidos.

${ }^{6}$ O termo "gíria", pelo qual índios e os não-índios em Roraima se referem correntemente às línguas indígenas, parece ter se difundido nos anos 50; vergonha e estigma são as suas conotações mais imediatas. Nega-se a elas o status de "línguas" (verdadeiras), reservado para o português. 
${ }^{7}$ Nessa ótica, o caso wapichana era, como se pode deduzir, aberrante. Voltaremos a isto mais adiante.

${ }^{8}$ Inaugurava-se, naqueles anos, o Projeto Calha Norte (PCN), programa militar brasileiro para a revivificação das fronteiras internacionais amazônicas através de sua ocupação por meio de bases, pelotões e vilas. Obviamente, boa parte do perímetro fronteiriço amazônico atravessa territórios indígenas, dividindo etnias entre dois ou mais países. O clima nas regiões de fronteiras - e Roraima é um estado de fronteira era, quando não abertamente tenso e de conflito, carregado de sentimentos nacionalistas na definição de "amigos e inimigos".

${ }^{9}$ A partir de 1948, a Missão da Consolata, com as missões de Normandia, Surumu e Maturuca, sucede aos Benedetinos, chegados ao alto Rio Branco no início do século XX.

${ }^{10}$ Utilizamos as convenções gráficas correntes para distinguir fone, entre colchetes; fonema, entre barras oblíquas; e grafema, entre barras verticais.

${ }^{11}$ Para entendermos que estamos diante de fenômenos nada exóticos no universo da escrita, vejamos a história da áurea valorativa do $<\mathrm{k}>$ em italiano contada por Cardona (1981:120): “[...] nessas últimas décadas, o $<\mathrm{k}>$ assumiu num primeiro momento, no uso italiano, conotações (irônicas) de modernidade [...] a partir de uma certa data, o < k > assume conotações negativas, políticas; depois do filme 'O Amerikano' de Costa Gravas, de 1972, onde o protagonista é um agente da CIA, o < k> se torna o elemento que conota o imperialismo, a repressão, a violência [...]".

${ }^{12}$ A preocupação com a adaptação à língua nacional e suas conseqüências marcam a grande maioria das experiências da escrita em populações indígenas. Gomez-Imbert (1998:s/p) escreve a partir de sua experiência entre os Tukano da Colômbia: "Estabelecer um sistema de escrita prático e adequado a ser usado na educação bilíngüe significa enfrentar problemas técnicos cuja solução é ideológica. Uma escrita 'boa' deve aproximar-se do português ou do espanhol [...] isso é ignorar as grandes diferenças estruturais que existem entre as línguas românicas e as línguas indígenas, como certas propriedades fonológicas e morfológicas que não podem ser representadas adequadamente pelas convenções usadas para o português ou o espanhol".

${ }^{13}$ Os Kuikuro são um dos quatro grupos locais falantes de uma língua pertencente à família karib, e estão localizados ao longo dos formadores orientais do rio Xingu, estado de Mato Grosso. São hoje cerca de 500 pessoas em quatro aldeias.

${ }^{14}$ A experiência da escrita entre os Kuikuro - experiência ao mesmo tempo do lingüista e dos próprios índios - é descrita e interpretada no texto publicado no catálogo da exposição homônima inaugurada no Museu Etnológico de Lisboa em dezembro de 2000 (Franchetto 2000).

${ }^{15}$ Essa representação da escrita está subjacente ao sentido da frase "não queremos misturar coisa de índio e coisa do branco", dita não poucas vezes por líderes 
tradicionais diante das propostas de implementação da educação bilíngüe nas escolas das aldeias, implicando resistência à "ortografização" de línguas indígenas e ao seu uso no espaço-tempo da instituição escolar (Franchetto 2001).

${ }^{16}$ Vê-se que a escrita kuikuro, como a dos Wapichana e de muitas outras línguas indígenas cujos falantes não acataram em sua integralidade o princípio "um fonema/ um grafema" (marco da lingüística americanista aplicada pelos missionários evangélicos e norma ideal), representa elementos distintivos e elementos subfonêmicos, como os que resultam de processos fonológicos de assimilação e "ressilabificação" (palatalizações, harmonia vocálica, vozeamento e pré-nasalização das oclusivas precedidas por nasal).

${ }^{17}$ Um exemplo típico é a oscilação na escrita de um mesmo indivíduo no que concerne ao estabelecimento de separações/ espaços entre palavras, nos quais conflitam constantemente a consciência da hegemonia da unidade "palavra" na escrita, com a realidade "palavra" na própria língua, com as junções e as fronteiras fonológicas, com a ambigüidade inerente, por exemplo, aos elementos clíticos.

${ }^{18}$ Esta é a prática de algumas experiências atuais. Nos seminários etnoeducacionais que aconteceram entre os Tukano da Colômbia, em certos cursos de formação de professores indígenas no Brasil, como os do Parque Indígena do Xingu, ou no $3^{\circ}$ Grau Indígenas da Universidade Estadual de Mato Grosso, cria-se uma metalinguagem para analisar explicitamente o conhecimento lingüístico e cultural por meio de reflexões e atividades coletivas. Os índios tornam-se conscientes da riqueza de suas línguas quando descobrem que elas obedecem a regras que podem ser trabalhadas e formuladas apropriadamente, e não são um mero amontoado de palavras (ou sons) como muitos dos brancos pensam e fazem os índios acreditar. 


\section{Referências bibliográficas}

Arquivo Indigenista da Diocese de Roraima. 1986. "Povos indígenas do nordeste de Roraima". Boletim n. 11.

BARROS, Maria Cândida D. M. 1993. Lingüística missionária: Summer Institute of Linguistics. Tese de doutorado em ciências sociais, Unicamp, Campinas.

CARDONA, Giorgio R. 1981. Antropologia della scrittura. Torino: Loescher Editore.

Centro de Informação da Diocese de Roraima. 1988. Igreja a Caminho, ano 4, n. 10.

Diocese de Roraima. 1983. Roraima Indígena, n. 2.

FRANCHETTO, Bruna. 1995. "O papel da educação escolar na domesticação das línguas indígenas pela escrita". Revista Brasileira de Estudos Pedagógicos, 75(179-181):409-421. . 2000. "Escrever línguas indígenas: Apropriação, domesticação, representações". Catálogo da Exposição Os Índios, Nós. Lisboa: Museu Nacional de Etnologia. pp. 44-50. . 2001. "Assessor, pesquisador: reflexões em torno de uma experiência em educação indígena" In: A. L. da Silva \& M. K. L. Ferreira (orgs.), Práticas pedagógicas em escolas indígenas. São Paulo: Global. pp. 87-106.

KAHN, Marina. 1986. "As Missões de Fé e os cursos de missiologia". Trabalho apresentado no Grupo de Trabalho sobre Política de Pesquisa Lingüística, as Missões de Fé e as Línguas Indí- genas, XV Reunião da Associação Brasileira de Antropologia, Curitiba, março de 1986. Ms.

GOMEZ-IMBERT, Elsa. 1998. "Writing the tukanoan languages: educational politics in the Vaupés area in Colombia and Brazil". Paper presented in $14^{\text {th }}$ Congress of Anthropological and Ethnological Sciences. Workshop "Politics and Culture in the Northwest Amazon". Williamsburg, July 1998. Ms.

Informativo do Setor Indígena da Diocese de Roraima. 1981a. Anna Maimu, Waparadan, 15. s/p.

Informativo do Setor Indígena da Diocese de Roraima. 1981b. Anna Maimu, Waparadan, 16. s/p.

NIDA, Eugene. 1957. Learning a foreign language. Cincinnati: Friendship Press.

RICARDO, Carlos A. (org.). 2000. Povos indígenas no Brasil, 1996-2000. São Paulo: Instituto Socioambiental.

STOLL, David. 1982. Fishers of men or founders of empire? The wycliffe bible translators in Latin America. London: Zed Press.

STEINEN, Karl von den. 1894. Unter den Naturvölkern Zentral-Brasiliens. Reiseschilderung und Ergebnisse der zweiten Schingú-Expedition 1887 1888. Berlin: Geographische Verlagsbuchhandlung von Dietrich Reimer. Tradução brasileira: SHADEN, Egon. 1940. "Karl von den Steinen. Entre os aborígenes do Brasil Central". Revista do Arquivo Municipal, pp. 34-68. 
Resumo

A partir de fragmentos etnográficos de experiências de pesquisa lingüística entre os Taurepáng, Macuxi, Wapichana e Kuikuro, em tempos, regiões e situações distintos, este artigo trata do confronto entre oralidade e escrita, quando a "ortografização" de uma língua indígena, falada por uma sociedade de tradição oral, transforma e cristaliza sons e ditos em folhas de papel. Em uma arena aberta, representações e agentes da escrita surgem, interagem, chocam-se: missionários, pesquisadores, homens do Estado, professores indígenas, pastores indígenas, índios etc. A escrita, neste contexto, é então abordada mais como metáfora ou emblema do que uma simples tecnologia de correspondências entre códigos. Trata-se, então, de uma interpretação do sentido da escrita que pode ajudar a entender, entre outras coisas, as razões de acertos e fracassos da "educação bilíngüe", do letramento e da escolarização. Os índios ainda observam, não poucas vezes perplexos, as guerras ou as danças das letras, enquanto a "ortografização" consagra o que ela permite e condena o que ela exclui, órgãos vitais de uma língua.

Palavras-chave: Etnologia, Escrita, Educação Indígena, Políticas Lingüísticas, Línguas Indígenas

\section{Abstract}

Based on ethnographic fragments from linguistic research among the Taurepáng, Macuxi, Wapichana and Kuikuro, conducted in distinct times, regions and situations, this article analyzes the conflict occurring between orality and writing when the 'orthographization' of an indigenous language transforms and crystallizes sounds and speech on sheets of paper. This is an open arena where different representations and agents of writing emerge, interact and clash: missionaries, researchers, agents of the state, indigenous teachers, indigenous preachers, the indigenous community itself and so on. Here I approach writing more as a metaphor or emblem than a simple technology of correspondences between codes. The article provides, then, an interpretation of the meaning of writing that may help us to understand, among other things, the reasons behind the successes and failures of 'bilingual education,' literacy projects and the introduction of schooling. The Indians also observe, often with considerable perplexity, the 'wars' or 'dances' of the letters, where 'orthographization' consecrates whatever it includes and condemns what it excludes the vital organs of a language.

Key words: Ethnology, Writing, Indigenous Education, Linguistic Policies, Indigenous Languages 